\title{
Pengaruh Pergantian CEO Pada Profitabilitas dengan Manajemen Laba Sebagai Variabel Pemoderasi
}

\section{Ni Putu Eka Kartika Putri ${ }^{1}$ I Wayan Ramantha ${ }^{2}$}

\author{
${ }^{1,2}$ Fakultas Ekonomi dan Bisnis Universitas Udayana (Unud), Bali, Indonesia \\ e-mail: ikakartikaptr203@gmail.com
}

\begin{abstract}
ABSTRAK
Penelitian ini di lakukan pada perusahaan manufaktur yang terdaftar di Bursa Efek Indonesia (BEI). Profitabilitas diproksikan dengan Return On Asset (ROA) dan manajemen laba dihitung dengan Discretionary Accrual Jones Modified. Pemilihan sampel dalam penelitian ini menggunakan purposive sampling dan jumlah perusahaan yang didapat adalah sebanyak 32 perusahaan manufaktur dengan jangka waktu 5 tahun pengamatan yaitu 2013-2017. Total sampel yang diuji yaitu 160 sampel. Teknik analisis yang digunakan adalah Moderated Regression Analysis (MRA). Berdasarkan hasil penelitian ditemukanbahwa manajemen laba memoderasi pergantian CEO pada profitabilitas perusahaan. Teknik manajemen laba yang ditemukan dalam penelitian ini adalah income minimization yaitu meminimalkan laba pada tahun berjalan.
\end{abstract}

Kata kunci: Pergantian CEO, profitabilitas, manajemen laba

\begin{abstract}
This research was conducted at manufacturing companies listed on the Indonesia Stock Exchange (IDX). Profitability is proxied by Return On Assets (ROA) and earnings management is calculated by the Discretionary Accrual Jones Modified. The sample selection in this study used purposive sampling and the number of sample companies taken was 32 manufacturing companies with a period of 5 years of observation, namely 2013. 2017. The total sample tested was 160 samples. The analysis technique used is Moderated Regression Analysis (MRA). Based on the results of the study it was stated that earnings management moderated the CEO turnover on the profitability of the company. The earnings management technique found in this study is income minimization which is minimizing earnings in the current year.
\end{abstract}

Keywords: CEO turnover, profitability, earnings management

\section{PENDAHULUAN}

Perusahaan umumnya dibentuk dengan tujuan untuk meningkatkan kesejahteraan pemilik perusahaan. Pemilik perusahaan tentu mengharapkan sebuah tingkat pengembalian dari sebuah investasi yang harus dapat diupayakan oleh tim manajemen (Setiaji \& Junarsin, 2014). Organisasi dipengaruhi oleh lingkungan mereka sesuai dengan cara-cara di mana manajer atau pemimpin merumuskan 
Ni Putu Eka Kartika Putri dan I Wayan Ramantha. Pengaruh ...

strategi, membuat keputusan, dan menerapkannya. Manajer yang sukses mampu baik untuk menjaga organisasi mereka dari gangguan lingkungan atau gangguan dari struktur organisasi yang memerlukan sedikit penyesuaian (Hannan \& Freeman, 1977). Manajer memiliki beberapa tingkatan atau level, yaitu: manajer tingkat pertama, manajer tingkat menengah, dan manajer puncak. Manajer puncak terdiri dari beberapa direktur, yang disebut dengan dewan direksi atau Board of Directors (Chandra, 2013).

Chief Executive Officer (CEO) merupakan eksekutif yang berada di puncak perusahaan dan yang bertanggung jawab untuk kelangsungan hidup dan keberhasilan perusahaan. Jabatan yang dipegang seperti ketua dewan perusahaan, direktur utama perusahaan, wakil presiden senior, wakil presiden pelaksana dan wakil presiden. Perusahaan yang dibagi menjadi unit bisnis strategis atau divisi operasi, maka orang yang memimpin unit ini juga merupakan manajer puncak (Wandeca, 2012). Terdapat dua jenis sistem hukum mengenai dewan direksi yaitu sistem satu tingkat (one tier) dan sistem dua tingkat (two tier). Sistem satu tingkat berasal dari sistem hukum Anglo Saxon. Pada sistem satu tingkat, perusahaan mempunyai satu dewan direksi yang merupakan kombinasi antara manajer atau pengurus senior (direktur eksekutif) dan direktur independen yang bekerja dengan prinsip paruh waktu (non direktur eksekutif).Sistem dua tingkat berasal dari sistem hukum kontinental Eropa. Pada sistem dua tingkat, perusahaan mempunyai dua badan terpisah, yaitu dewan pengawas (dewan komisaris) dan dewan manajemen (dewan direksi). Dewan direksi bertugas mengelola dan mewakili perusahaan sesuai dengan pengarahan dan pengawasan dewan komisaris. Dewan 
direksi diangkat dan setiap waktu dapat diganti oleh badan pengawas (dewan komisaris). Tugas utama dewan komisaris adalah bertanggungjawab mengawasi tugas-tugas manajemen. Indonesia termasuk negara yang mengadopsi sistem dua tingkat ini (Ratnasari, 2011). CEO yang dimaksud dalam penelitian ini adalah presiden direktur atau direktur utama perusahaan.Persaingan tenaga kerja juga terjadi antara kalangan manajerpuncak. CEO disini sebagai manajer puncak harus dapat membuktikan kepada stakeholders bahwa kinerjanya selama memimpin sebuah perusahaan sangat baik. CEO dengan penilaian kinerja yang baik ketika masa jabatannya telah selesai, memiliki kesempatan yang lebih besar untuk ditawarkan pekerjaan yang lebik baik. Kinerja CEO yang kurang baik dan tidak bisa menunjukkan perkembangan perusahaan kearah yang lebih baik atau bahkan merugikan perusahaan, akan memiliki kemungkinan diganti sebelum masa jabatannya selesai.

Event pergantian CEO merupakan event yang pasti terjadi dalam sebuah perusahaan. Terdapat dua jenis pergantian CEO, yaitu pergantian rutin dan nonrutin (Adiasih \& Kusuma, 2011). CEO sebagai pemimpin perusahaan memegang tanggung jawab yang besar terhadap nilai dari perusahaan yang dipimimpinnya karena stakeholders dalam memutuskan akan berinvestasi atau tidak pada suatu perusahaan melihat salah satunya dari nilai perusahaan tersebut. Pergantian CEO suatu perusahaan kemungkinan akan diikuti dengan redefinisi misi,visi, dan strategi bisnis, sehingga menuntut adanya restrukturisasi organisasi yang sesuai dengan formulasi misi, visi, dan strategi yang baru tersebut. 
Ni Putu Eka Kartika Putri dan I Wayan Ramantha. Pengaruh ...

Penggantian ini seharusnya mampu memicu peningkatan kinerja perusahaan tersebut (Trisnantari, 2008).

Laba menjadi salah satu tolak ukur dalam kinerja suatu perusahaan. Pernyataan ini sesuai dengan pernyataan dalam Statement of Financial Accounting Concept (SFAC) No.1 tahun 1978 yaitu fokus utama dari pelaporan keuangan adalah informasi mengenai prestasi suatu entitas bisnis yang diukur dengan laba dan komponen-komponen lainnya (Astika, 2010;122). PSAK 1 no. 9 menyatakan bahwa tujuan laporan keuangan adalah untuk memberikan informasi mengenai kinerja keuangan yang salah satunya dilihat dari laba perusahaan (PSAK, 2017). Informasi mengenai laba dapat digunakan oleh pihak eksternal perusahan untuk menilai bagaimana kinerjaperusahaan selama satu periode. Informasi laba juga dapat mempengaruhi pengambilan keputusan bagi para calon investor maupun kreditor.

Kinerja perusahaan yang baik akan meningkatkan nilai perusahaan di mata stakeholders. Nilai perusahaan dapat dinilai salah satunya dengan bagaimana profitabilitas dari perusahaan tersebut. Profitabilitas adalah kemampuan perusahaan memperoleh laba atau ukuran efektifitas pengelolaan manajemen perusahaan (Wiagustini, 2014;86). Profitabilitas adalah hasil akhir dari sejumlah kebijakan dan keputusan yang dilakukan oleh perusahaan (Brigham \& Houston, 2006;107). Kemampuan memperoleh laba bisa diukur dari modal sendiri maupun dari seluruh dana yang diinvestasikan ke dalam perusahaan. Pengukuran profitabilitas suatu perusahaan harus diketahui terlebih dahulu berapa laba perusahaan yang diperoleh pada suatu periode tertentu dan berapa modal sendiri 
yang digunakan atau berapa jumlah nilai investasi yang digunakan untuk memperoleh laba tersebut (Wiagustini, 2014;86). Profitabilitas diukur menggunakan rasio profitabilitas. Rasio profitabilitas yaitu sekelompok rasio yang menunjukkan gabungan efek-efek dari likuiditas, manajemen aktiva, dan utang pada hasil operasi (Brigham \& Houston, 2006;107). Rasio likuiditas yang digunakan dalam penelitian ini adalah Return on Assets (ROA). Profitabilitas dapat mengilustrasikan kemampuan perusahaan dalam menghasilkan laba atau ukuran efektivitas penyelenggaraan manajemen perusahaan. Tingginya profitabilitas yang dimiliki perusahaan dapat mengandung berita baik dalam laporan keuangaannya (Ajeng Ferdina \& Wirama, 2017).

Laporan keuangan memiliki informasi laba yang sangat diperlukan untuk membuat sebuah keputusan. Pihak manajemen menyadari bahwa perhatian stakeholders terfokus terhadap informasi laba, khususnya manajer yang kinerjanya diukur berdasarkan informasi tersebut. Hal ini mendorong timbulnya perilaku menyimpang oleh para manajer yang salah satu bentuknya adalah manajemen laba (Boediono, 2005). Manajemen laba terjadi ketika manajemen menggunakan pertimbangan (judgment) dalam pelaporan keuangan dan dalam penyusunan transaksi untuk mengubah laporan keuangan baik dengan tujuan untuk menyesatkan beberapa pemangku kepentingan tentang kinerja ekonomi perusahaan atau untuk mempengaruhi hasil kontrak (contractual outcomes) yang bergantung pada angka akuntansi yang dilaporkan (Healy \& Wahlen, 1999).

Earnings management dibagi menjadi 2 definisi, yaitu definisi sempit dan definisi luas. Secara sederhana, dijelaskan bahwa manajemen laba hanya berkaitan 
Ni Putu Eka Kartika Putri dan I Wayan Ramantha. Pengaruh ...

dengan pemilihan metode akuntansi. Selain itu juga diartikan sebagai perilaku manajer untuk "bermain" dengan komponen discretionary accruals dalam menentukan besarnya earnings. Sedangkan dalam definisi luasnya, manajemen laba merupakan tindakan manajer untuk meningkatkan atau mengurangi laba yang dilaporkan saat ini atas suatu unit dimana manajer bertanggung jawab tanpa mengakibatkan peningkatan atau penurunan profitabilitas ekonomi jangka panjang unit tersebut Sugiri,1998 dalam Agnes (2001).Terdapat pandangan yang berbeda-beda terhadap praktik manajemen laba. Pada satu sisi, manajemen laba dipandang sebagai suatu tindakan yang seharusnya tidak boleh dilakukan karena dengan adanya manajemen laba infomasi yang diberikan tidak sepenuhnya mencerminkan keadaan perusahaan dan mengaburkan nilai perusahaan sesungguhnya. Tindakan tersebut dapat menyebabkan stakeholders keliru dalam mengambil keputusan. Sisi yang lain, manajemen laba dianggap sebagai sesuatu yang wajar dan merupakan tindakan rasional untuk memanfaatkan fleksibilitas dalam ketentuan untuk pelaporan keuangan (Kaudin, 2015).

Manajemen laba yang dilakukan oleh manajer tidak terlepas dari faktor-faktor yang mempengaruhi keleluasaan seorang manajer untuk menerapkan teknikteknik agar dapat menaikkan atau menurunkan laba perusahaannya (Yasa \& Novialy, 2012). Terdapat dua basis pencatatan transaksi dalam akuntansi, yaitu basis kas (cash basis) dan basis akrual (accrual basis). Pencatatan dengan basis kas dipandang tidak mampu menginformasikan keadaan keuangan perusahaan yangsebenarnya karena dari sisi penandingan basis ini menyebabkan hilangnya kesempatan untuk menandingkan pendapatan dengan biaya pada satu-satuan 
waktu tertentu. Kenyataan inilah yang kemudian membuat basis akrual, yang mampu memberikan peluang kepada manajemen untuk menandingkan pendapatan dengan biayanya pada satu satuan waktu tertentu (matching principle), menjadi basis yang diterapkan secara luas dalam lingkungan bisnis saat ini (Astika, 2010). Penggunaan basis akrual, dalam praktiknya, ternyata menimbulkan masalah tersendiri. Hal ini disebabkan karena dalam akrual terdapat akrual diskresioner (discretionary accruals), yakni akrual yang diskresinya (keleluasaan keputusan penggunaannya) berada di tangan manajemen. Melalui akrual diskresioner, seorang manajer dapat menaikkan, menurunkan ataupun meratakan labanya tanpa perlu melanggar standar akuntansi keuangan yang ada (Erawan \& Ulupui, 2013). Pernyataan tersebut sesuai dengan hasil penelitian Wijaya \& Ardiana (2014) yang menemukan adanya manajemen laba dengan pola income decreasing dan income increasing yang dilakukan oleh manajemen pada saat event pergantian Chief Executive Officer (CEO).

Chandra (2013) dalam penelitiannya mengenai pengaruh pergantian CEO terhadap kinerja perusahaan dengan manajemen laba sebagai variabel intervening menemukan bahwa pergantian CEO melalui manajemen laba sebagai variabel intervening tidak berpengaruh terhadap kinerja perusahaan. Kanga \& Shivdasani (1995) juga meneliti mengenai pergantian CEO dan hubungannya dengan kinerja perusahaan. Hasil penelitian yang didapatkan adalah pergantian CEO nonrutin berpengaruh secara signifikan negatif terhadap kinerja perusahaan sedangkanpergantian CEO rutin tidak berpengaruh terhadap kinerja dan pergantian CEO nonrutin berpengaruh signifikan terhadap return on assets 
Ni Putu Eka Kartika Putri dan I Wayan Ramantha. Pengaruh ...

(ROA), kelebihan pendapatan, dan laba sebelum pajak. Setiaji \& Junarsin (2014) dalam penelitiannya menemukan bahwa pengaruh Pergantian CEO terhadap kinerja perusahaan yang diukur dengan ROA tidak memiliki hubungan yang signifikan.

Muravyev et al (2009) menyatakan hasil penelitian dari pengaruh pergantian manajerial dengan kinerja perusahaan di Ukraina berpengaruh negatif. Muravyev dalam penelitiannya menggunakan ROA untuk mengukur kinerja perusahaan di Ukraina. Hasil yang sama juga ditemukan oleh Rachpradit, Tang, \& Khang (2015) dalam penelitiannya mengenai pengaruh pergantian CEO terhadap kinerja perusahaan di Thailand.

Penelitian mengenai manajemen laba pada event pergantian CEO telah dilakukan sebelumnya oleh Feng Yu (2012), Hazarika, Karpoff, \& Nahata (2011), Erawan \& Ulupui (2013), serta Wijaya \& Ardiana (2014). Sadia \& Sukartha (2011) serta Dhinata \& Wirama (2015) melakukan penelitian mengenai kemungkinan terjadinya praktik manajemen laba dengan pola income decreasingyang dilakukan oleh CEO yang baru menjabat dan mendapatkan hasil bahwa benar terbukti CEO yang baru menjabat melakukan income decreasing. Penelitian mengenai manajemen laba yang dilakukan oleh Erawan \& Ulupui, (2013), Wijaya \& Ardiana (2014) serta Dewi \& Rasmini (2018) meneliti adanya manajemen laba sebelum dan sesudah pergantian CEO. Hasil yang didapatkan adalah bahwa ditemukan adanya praktik manajemen laba dengan pola income decreasing yang dilakukan oleh CEO baru setelah pergantian $\mathrm{CEO}$, dan juga ditemukan adanya praktik manajemen laba dengan pola income increasing yang 
dilakukan oleh CEO lama pada akhir masa jabatanya menjelang pergantian CEO. Wijaya \& Ardiana (2014) menekankan manajemen laba dengan pola income increasing dan income decreasing pada sebelum dan sesudah pergantian CEO terjadi baik pergantian CEO tersebut dilakukan secara rutin maupun nonrutin. Berbeda dengan hasil penelitian yang dilakukan oleh Ung (2009) mengenai manajemen laba disekitar event pergantian CEO, CEO lama tidak terbukti melakukan income increasing baik dalam pergantian CEO secara rutin maupun pergantian CEO secara nonrutin. Ung (2009) juga tidak menemukan adanya income decreasing yang dilakukan oleh CEO yang baru menjabat. Namun ditemukan adanya 'earning bath' oleh CEO yang baru menjabat pada masa pergantian CEO baik pergantian secara rutin maupun pergantian secara nonrutin. Hal serupa mengenai tidak ditemukannya praktik manajemen laba pada event pergantian CEO juga didapatkan oleh Adiasih \& Kusuma (2011). Dalam penelitiannya Adiasih \& Kusuma (2011) tidak berhasil membuktikan terjadinya manajemen laba pada peristiwa pergantian CEO rutin. Selain itu, pada peristiwa pergantian CEO secara nonrutin, CEO lama pada tahun terakhir sebelum terjadinya pergantian tidak terbukti melakukan praktik manajemen laba.

Penelitiann ini merupakan pengembangan dari penelitian sebelumnya yang mengangkat topik mengenai pergantian CEO, profitabilitas, dan manajemen laba. Adanya inkonsistensi hasil penelitian antara pengaruh pergantian CEO dengan manajemen laba dan pengaruh pergantian CEO dengan kinerja perusahaan yang diukur dengan menggunakan ROA yang merupakan salah satu rasio profitabilitas, membuat penelitian ini menarik untuk diteliti. Alasan lain penelitian ini menarik 
Ni Putu Eka Kartika Putri dan I Wayan Ramantha. Pengaruh ...

karena pada event pergantian CEO, CEO baru memiliki tanggung jawab untuk mengelola perusahaan dan memperoleh laba yang lebih baik dari periode sebelumnya. Adanya akrual diskresioner yang dapat memicu terjadinya manajemen laba baik dalam konotasi positif maupun negatif, dapat mengurangi kualitas informasi laba yang dihasilkan dan dapat menyesatkan pengguna laporan keuangan dalam membuat suatu keputusan. Penelitian pengaruh pergantian CEO pada profitabilitas dengan menambahkan variabel manajemen laba sebagai variabel pemoderasi merupakan penelitian yang belum pernah diteliti sebelumnya.

CEO sebagai manajer puncak memiliki tanggung jawab dalam memastikan perusahaan memiliki kinerja yang baik sehingga dianggap pantas untuk berinvestasi di perusahaaan tersebut. CEO dapat melakukan manajemen laba agar perusahaan yang dipimpinnya memiliki nilai yang baik. Manajemen dengan keleluasaannya untuk menaikkan, menurunkan ataupun meratakan laba, dapat mengganggu kualitas laporan keuangan yang disajikan. Laba yang disajikan dalam laporan keuangan setelah adanya manajemen laba dapat menyesatkan pengguna laporan keuangan dalam mengambil sebuah keputusan.

Salim (2015) dalam penelitiannya mengenai hubungan manajemen laba terhadap profitabilitas perusahaann mengungkapkan bahwa manajemen laba berpengaruh terhadap profitabilitas perusahaan. Hal serupa juga ditemukan oleh Sulistiani \& Maha, (2012), manajemen laba berpengaruh terhadap profitabilitas perusahaan yang dalam penelitiannya diukur menggunakan ROA. Manajemen laba berkontribusi mempengaruhi naik turunnya return on assets. Berdasarkan uraian diatas maka hipotesis yang diajukan dalam penelitian ini. 
$\mathrm{H}_{1}$ : Manajemen laba memoderasi pengaruh pergantian CEO pada profitabilitas.

\section{METODE PENELITIAN}

Penelitian ini dilakukan pada perusahaan-perusahaan manufaktur yang terdaftar dalam Bursa Efek Indonesia dan informasi mengenai laporan keuangan dan laporan tahunan disediakan oleh Bursa Efek Indonesia yang diakses melalui www.idx.co.id. Obyek penelitian ini adalah Profitabilitas perusahaan-perusahaan manufaktur yang terdaftar dalam Bursa Efek Indonesia dan mengalami pergantian CEO.

Profitabilitas dalam penelitian ini diukur dengan menggunakan ROA karena sampel dari penelitian ini adalah perusahaan manufaktur, dimana perusahaan manufaktur banyak menggunakan aset tetap dalam melakukan operasional perusahaan. Aset tetap berfungsi untuk mendukung menjalankan kegiatan perusahaan, yaitu kegiatan yang dilakukan perusahaan dalam rangka memperoleh dana. Pengelolaan aset secara efektif dan efisien otomatis dapat meningkatkan keuntungan atau profit perusahaan (Affandi, 2017)

Profitabilitas dapat diukur dengan rumus:

$R O A=\frac{\text { laba bersih setelah pajak }}{\text { total aktiva }} \times 100 \%$

Healy \& Wahlen (1999) mendefinisikan manajemen laba adalah ketika manajemen menggunakan pertimbangan (judgment) dalam pelaporan keuangan dan dalam penyusunan transaksi untuk mengubah laporan keuangan baik dengan tujuan untuk menyesatkan beberapa pemangku kepentingan tentang kinerja 
Ni Putu Eka Kartika Putri dan I Wayan Ramantha. Pengaruh ...

ekonomi perusahaan atau untuk mempengaruhi hasil kontrak (contractual outcomes) yang bergantung pada angka akuntansi yang dilaporkan.

Manajemen laba dalam penelitian ini diproksikan dengan discretionary accrual jones modified. Model ini dipilih karena model ini merupakan model pendeteksi manajemen laba yang umum digunakan dalam riset-riset empiris mengenai manajemen laba di Indonesia.

Manajemen laba yang diproksi dengan discretionary accrual dengan menggunakan model Jones yang dimodifikasi (Dechow et al., 2011) dengan langkah sebagai berikut:

\section{Total accrual}

$\mathrm{TAC}_{\mathrm{it}}=\mathrm{N}_{\mathrm{it}}-\mathrm{CFO}_{\mathrm{it}}$

Keterangan:

$\mathrm{TAC}_{\mathrm{t}} \quad$ : Total accruals perusahaan i pada periode $\mathrm{t}$

$\mathrm{N}_{\mathrm{it}} \quad$ : Laba bersih perusahaan i pada periode $\mathrm{t}$

$\mathrm{CFO}_{\text {it }} \quad$ : Aliran kas dari aktivitas operasi perusahaan i pada periode $\mathrm{t}$

Total accrual yang diestimasi dengan persamaan regresi OLS (Ordinary

\section{Least Square)}

$\mathrm{TAC}_{\text {it }} / \mathrm{A}_{\mathrm{it}-1}=\beta_{1}\left(1 / \mathrm{A}_{\mathrm{it}-1}\right)+\beta_{2}\left(\Delta \mathrm{REV}_{\mathrm{t}} / \mathrm{A}_{\mathrm{it}-1}\right)+\beta_{3}\left(\mathrm{PPE}_{\mathrm{it}} / \mathrm{A}_{\mathrm{it}-1}\right)+\mathrm{e}$

Keterangan:

TAC $_{\mathrm{t}} \quad$ : Total accruals perusahaan $\mathrm{i}$ pada periode $\mathrm{t}$

$\mathrm{A}_{\mathrm{it}-1} \quad:$ Total Aset perusahaan i pada periode t-1

$\triangle \mathrm{REV}_{\mathrm{t}} \quad:$ Perubahaan pendapatan perusahaan i dari tahun $\mathrm{t}-1$ ke tahun $\mathrm{t}$

$\mathrm{PPE}_{\mathrm{it}} \quad:$ Aset tetap perusahaan tahun $\mathrm{t}$

$\beta_{1-3} \quad:$ Koefisien regresi

e : error

Non discretionary accruals

$\mathrm{NDA}_{i t}=\beta_{1}\left(1 / \mathrm{A}_{\mathrm{it}-1}\right)+\beta_{2}\left(\Delta \mathrm{REV}_{\mathrm{t}} / \mathrm{A}_{\mathrm{it}-1}-\Delta \mathrm{REC}_{\mathrm{t}} / \mathrm{A}_{\mathrm{it}-1}\right)+\beta_{3}\left(\mathrm{PPE}_{\mathrm{it}} / \mathrm{A}_{\mathrm{it}-1}\right)$ 
Keterangan:

$\mathrm{NDA}_{\text {it }} \quad$ : Non Discretionary Accruals perusahaan i pada periode ke t

$\mathrm{A}_{\mathrm{it}-1} \quad$ : Total Aset perusahaan i pada periode $\mathrm{t}$

$\triangle \mathrm{REV}_{\mathrm{t}} \quad:$ Perubahaan pendapatan perusahaan dari tahun $\mathrm{t}-1$ ke tahun $\mathrm{t}$

$\triangle \mathrm{REC}_{\mathrm{t}} \quad:$ Perubahan piutang perusahaan i dari tahun $\mathrm{t}-1$ ke tahun $\mathrm{t}$

$\mathrm{PPE}_{\mathrm{it}} \quad$ : Aset tetap perusahaan tahun $\mathrm{t}$

$\beta_{1-3} \quad$ : Koefisien regresi

Discretionary total accrual

$\mathrm{DA}_{\mathrm{it}}=\mathrm{TAC}_{\mathrm{it}} / \mathrm{A}_{\mathrm{it}-1}-\mathrm{NDA}_{\mathrm{i}}$

Keterangan:

$\mathrm{DA}_{\mathrm{it}} \quad$ : Discretionary Accruals perusahaan i pada periode ke $\mathrm{t}$

TAC $_{\text {it }} \quad$ : Total accrual perusahaan i pada tahun $\mathrm{t}$

$\mathrm{A}_{\mathrm{it}-1} \quad$ : Total Aset perusahaan i pada periode $\mathrm{t}$

$\mathrm{NDA}_{\mathrm{it}} \quad$ : Non discretionary accruals pada tahun $\mathrm{t}$

Uji hipotesis moderasi dalam penelitian ini diuji dengan menggunakan analisis regresi moderasian atau uji interaksi. Model regresi moderasian penelitian ini ditunjukkan sebagai berikut:

$$
Y i=\alpha+\beta 1 X i+\beta 2 Z i+\beta 3 X i^{*} Z i+\varepsilon
$$

Keterangan:

Y : Profitabilitas

$\alpha \quad$ : Konstanta

$\beta 1-\beta 3$ : Koefisien regresi

$Z i \quad$ : Manajemen laba

$X i \quad$ : Pergantian CEO

$X i^{*} Z i$ : Interaksi pergantian CEO dan manajemen laba

$\varepsilon \quad$ : variabel pengganggu

\section{HASIL DAN PEMBAHASAN}

Analisis statistik deskriptif memberikan gambaran atau deskripsi suatu data yang dilihat dari nilai rata-rata (mean), standar deviasi, varian, maksimum, minimum. Analisis dari statistik deskriptif terdapat dalam tabel 1. 
Tabel 1.

Statistik Deskriptif Data Uji

\begin{tabular}{lccccc}
\hline & N & Minimum & Maximum & Mean & $\begin{array}{c}\text { Std. } \\
\text { Deviation }\end{array}$ \\
\hline Pergantian CEO & 160 & 0 & 1 & 0,20 & 0,40 \\
Profitabilitas & 160 & $-13,58$ & 26,15 & 5,06 & 6,38 \\
Manajemen Laba & 160 & $-8,45$ & 2,89 & $-0,31$ & 1,02 \\
P.CEO*M.LABA & 160 & $-1,78$ & 1,17 & $-0,054$ & 0,24 \\
Valid N & 160 & & & &
\end{tabular}

Variabel pergantian CEO memiliki nilai rata-rata sebesar 0,20. Nilai ratarata tersebut mendekati nilai minimum yaitu 0 . Hasil ini menunjukkan bahwa secara umum rata-rata perusahaan manufaktur yang menjadi sampel dalam penelitian ini tidak banyak terjadi event pergantian CEO.

Variabel Profitabilitas yang diproksikan dengan return on assets (ROA) memiliki nilai rata-rata sebesar 5,06. Nilai rata-rata tersebut mendekati nilai minimum yaitu $-13,58$. Hasil ini menunjukkan bahwa secara umum nilai rata-rata perusahaan manufaktur yang menjadi sampel dalam penelitian ini memiliki profitabilitas yang rendah.

Variabel manajemen laba yang diproksikan dengan discretionary accrual(DA) memiliki nilai rata-rata sebesar $-0,31$. Nilai rata-rata tersebut mendekati nilai maksimum yaitu sebesar 2,89. Hasil ini menunjukkan bahwa secara umum nilai rata-rata perusahaan manufaktur yang menjadi sampel dalam penelitian ini melakukan manajemen laba yaitu meminimalkan laba atau income minimization.

Uji normalitas dalam pennelitian ini menggunakan Kolmogrovv-Smirnov. Hasil dari uji normalitas disajikan dalam tabel 2 
Tabel 2.

Hasil Uji Normalitas

\begin{tabular}{llr}
\hline & & Unstandardized Residual \\
\hline $\mathrm{N}$ & & 160 \\
Normal Parameters $^{\mathrm{a}, \mathrm{b}}$ & Mean & 0,00 \\
& Std. Deviation & 6,09 \\
Most Extreme Differences & Absolute & 0,89 \\
& Positive & 0,89 \\
& Negative & $-0,40$ \\
Kolmogorov-Smirnov Z & & 1,12 \\
Asymp. Sig. (2-tailed) & & 0,15 \\
\hline Sumber: Data diolah, 2018 & &
\end{tabular}

Berdasarkan hasil uji normalitas yang disajikan dalam Tabel 2 didapatkan hasil asymp. sig. sebesar 0,15. Hasil ini lebih besar dari level of significant yaitu $5 \%(0,05)$. Kesimpulan dari hasil uji normalitas adalah bahwa data yang diuji menyebar normal atau berdistribusi normal. Uji autokorelasi bertujuan menguji apakah dalam model regresi linear ada korelasi antara kesalahan pengganggu pada periode $\mathrm{t}$ dengan kesalahan pengganggu pada periode t-1 (sebelumnya).

Tabel 3.

\section{Hasil Uji Autokorelasi}

\begin{tabular}{cccccc}
\hline Model & $\mathrm{R}$ & R Square & $\begin{array}{c}\text { Adjusted R } \\
\text { Square }\end{array}$ & $\begin{array}{c}\text { Std. Error of } \\
\text { the Estimate }\end{array}$ & Durbin-Watson \\
\hline $\mathbf{1}$ & 0,29 & 0,08 & 0,06 & 6,15 & 1,81 \\
\hline
\end{tabular}

Sumber :Data diolah, 2018

Hasil uji autokorelasi pada Tabel 3 menunjukkan nilai Durbin-Watson (d) sebesar 1,81. Level of significant yang digunakan adalah sebesar 5\% $(0,05)$ dan jumlah variabel bebas $(\mathrm{k})$ sebanyak 1 variabel, maka diperoleh nilai $\mathrm{d}_{\mathrm{L}}$ sebesar 1,7289 dan nilai $d_{U}$ sebesar 1,7541 serta nilai dari $\left(4-d_{U}\right)$ adalah sebesar 2,2459. Didapatkan hasil bahwa nilai $\left(4-\mathrm{d}_{\mathrm{U}}\right)$ lebih besar dari nilai ddan nilai d lebih besar dari nilai $\mathrm{d}_{\mathrm{U}}\left(\left(4-\mathrm{d}_{\mathrm{U}}\right)>\mathrm{d}>\mathrm{d}_{\mathrm{U}}\right)$, maka dapat disimpulkan bahwa $\mathrm{d}$ statistik berada pada daerah tidak terdapat autokorelasi atau model regresi yang dibuat tidak 
Ni Putu Eka Kartika Putri dan I Wayan Ramantha. Pengaruh ...

mengandung gejala autokorelasi, sehingga layak untuk digunakan dalam penelitian ini.

Uji heteroskedastisitas bertujuan menguji apakah dalam model regresi terjadi ketidaksamaan variance dari residual satu pengamatan ke pengamatan lain. Jika variance dari residual satu pengamatan ke pengamatan lain tetap, maka disebut Homoskedastisitas dan jika berbeda disebut Heteroskedastisitas. Model regresi yang baik adalah yang Homoskedastisitas atau tidak terjadi Heteroskedastisitas.

Tabel 4.

Hasil Uji Heteroskedastisitas

\begin{tabular}{|c|c|c|c|c|c|c|}
\hline \multicolumn{2}{|r|}{ Model } & \multicolumn{2}{|c|}{$\begin{array}{l}\text { Unstandardized } \\
\text { Coefficients }\end{array}$} & \multirow{2}{*}{$\begin{array}{c}\text { Standardized } \\
\text { Coefficients }\end{array}$} & \multirow[t]{2}{*}{$\mathrm{T}$} & \multirow[t]{2}{*}{ Sig. } \\
\hline & & B & Std. Error & & & \\
\hline \multirow[t]{4}{*}{1} & (Constant) & 4,711 & 0,363 & & 12,986 & 0,000 \\
\hline & Pergantian CEO & 0,307 & 0,875 & 0,032 & 0,351 & 0,726 \\
\hline & M. Laba & 0,205 & 0,311 & 0,054 & 0,659 & 0,511 \\
\hline & P.CEO*M.LABA & 0,402 & 1,472 & 0,025 & 0,273 & 0,785 \\
\hline
\end{tabular}

Sumber: Data diolah, 2018

Level of significant yang digunakan untuk pengujian heteroskedastisitas dalam penelitian ini adalah sebesar 0,05. Hasil uji heteroskedastisitas dapat dilihat dalam Tabel 4.5 dan nilai sig. pergantian CEO adalah sebesar 0,726, nilai sig manajemen laba adalah sebesar 0,511 dan nilai sig. P.CEO*M.Laba adalah sebesar 0,785. Nilai sig. tiap variabel lebih besar dari level of significant yang ditentukan maka dapat disimpulkan bahwa model yang dibuat tidak mengandung gejala heteroskedastisitas, sehingga layak digunakan untuk digunakan.

Penelitian ini menggunakan Moderated Regression Analysis (MRA) dalam model persamaan regresi linear untuk mengetahui kemampuan manajemen laba 
dalam memoderasi pengaruh pergantian CEO pada profitabilitas. Hasil dari pengujian MRA disajikan pada tabel 5.

Tabel 5.

Hasil Uji MRA

\begin{tabular}{|c|c|c|c|c|c|c|}
\hline \multirow{2}{*}{\multicolumn{2}{|c|}{ Model }} & \multicolumn{2}{|c|}{$\begin{array}{l}\text { Unstandardized } \\
\text { Coefficients }\end{array}$} & \multirow{2}{*}{$\begin{array}{c}\text { Standardized } \\
\text { Coefficients } \\
\text { Beta }\end{array}$} & \multirow[t]{2}{*}{$\mathrm{t}$} & \multirow[t]{2}{*}{ Sig. } \\
\hline & & $\mathrm{B}$ & $\begin{array}{l}\text { Std. } \\
\text { Error }\end{array}$ & & & \\
\hline \multirow[t]{7}{*}{1} & (Constant) & 4,416 & 0,570 & & 7,749 & 0,000 \\
\hline & Pergantian CEO & 0,055 & 1,374 & 0,003 & 0,040 & 0,968 \\
\hline & M.Laba & $-0,976$ & 0,489 & $-0,156$ & $-1,996$ & 0,048 \\
\hline & P.CEO*M.LABA & $-5,829$ & 2,313 & $-0,221$ & $-2,520$ & 0,013 \\
\hline & Adjusted $\mathrm{R}^{2}$ & 0,293 & & & & \\
\hline & $\mathrm{F}_{\text {hitung }}$ & 4,901 & & & & \\
\hline & Sig. F & 0,003 & & & & \\
\hline
\end{tabular}

Sumber: Data diolah, 2018

Berdassarkan tabel 5 dapat dibuat persamaan regresi sebagai berikut:

$$
\mathrm{Y}=4,416+0,055 \text { P.CEO }- \text { 0,976 M.Laba }-5,829 \text { P.CEO*M.Laba }+\varepsilon
$$

Nilai konstanta 4,416 menunjukkan apabila nilai pergantian CEO dan manajemen laba sama dengan nol, maka profitabilitan akan meningkat sebesar 4,416 .

Nilai koefisien regresi P.CEO sebesar 0,055 menunjukkan bahwa bila terjadi pergantian CEO, maka profitabilitas akan mengalami kenaikan sebesar 0,055 satuan dengan asumsi variabel lainnya konstan. Nilai koefisien regresi M.Laba sebesar -0,976 menunjukkan bahwa bila manajemen laba naik satu satuan, maka profitabilitas akan mengalami penurunan sebesar 0,976 satuan dengan asumsi semua variabel lainnya konstan. Nilai koefisien regresi P.CEO*M.Laba sebesar $-5,829$ menunjukkan bahwa bila interaksi antara pergantian CEO dengan manajemen laba naik satu satuan, maka profitabilitas 
Ni Putu Eka Kartika Putri dan I Wayan Ramantha. Pengaruh ...

akann mengalami penurunan sebesar 5,829 satuan dengan asumsi variabel lainnya konstan.

Hasil pengujian kesesuaian model dalam penelitian yang disajikan pada tabel 5 menunjukkan bahwa nilai dari uji $\mathrm{F}$ adalah sebesar 4,901 dan nilai sig. $F$ adalah sebesar 0,003 yang merupakan lebih kecil dari nilai $\alpha=0,05$. Hal ini menunjukkan bahwa model persamaan dalam penelitian ini layak untuk digunakan.

Berdasarkan Tabel 5 diperoleh nilai sig. dari P.CEO*M.Laba adalah sebesar 0,013. Nilai sig. lebih kecil dari batas signifikansi yaitu $0,05(0,013<0,05)$, maka $\mathrm{H}_{1}$ diterima dan $\mathrm{H}_{0}$ ditolak. Nilai $\mathrm{B}$ negatif menunjukkan bahwa variabel P.CEO*M.Laba memiliki hubungan yang berlawanan arah dengan profitabilitas. Hasil pengujian hipotesis kedua dapat disimpulkan bahwa manajemen laba merupakan variabel pemoderasi dari pengaruh pergantian CEO pada profitabilitas perusahaan yang dalam penelitian ini diproksikan dengan ROA.

Koefisien determinasi dilihat melalui nilai adjusted $R$ square yang dapat dilihat pada Tabel 5. Nilai adjusted $R$ aquare sebesar 0,069 memiliki arti bahwa 6,9\% variasi perubahan profitabilitas dapat dijelaskan oleh variabel Pergantian CEO, sedangkan 93,1\% dipengaruhi oleh variabel lain diluar dari model regresi yang digunakan.

Hasil pengujian hipotesis menunjukkan bahwa manajemen laba memoderasi pengaruh pergantian CEO pada profitabilitas perusahaan yang dalam penelitian ini diproksikan dengan ROA. Hasil ini terbukti menerima hipotesis satu $\left(\mathrm{H}_{1}\right)$ yang menyatakan bahwa manajemen laba memoderasi pengaruh pergantian 
CEO pada profitabilitas. Variabel interaksi pergantian CEO dengan manajemen laba memiliki hubungan yang berlawanan arah dengan profitabilitas yang dapat dilihat dari nilai B yang negatif. Hubungan yang berlawanan arah adalah semakin banyak partisipasi CEO baru dalam melakukan praktik manajemen laba, maka profitabilitas perusahaan akan semakin turun.

Manajemen laba yang dalam penelitian ini diukur dengan menggunakan descretoinary accrual yang mendapatkan hasil bahwa secara umum rata-rata perusahaan manufaktur yang menjadi sampel dalam penelitian ini melakukan manajemen laba yaitu meminimalkan laba atau income minimization. Income minimization adalah praktik manajemen laba dengan cara menjadikan laba pada laporan keuangan periode berjalan lebih rendah daripada laba sesungguhnya. Income minimization dilakukan ketika tingkat profitabilitas perusahaan cukup tinggi, sehingga jika pada periode selanjutnya perusahaan memiliki tingkat profitabilitas yang rendah atau turun drastis maka dapat diatasi dengan mengambil laba pada periode sebelumnya. Political cost hypothesis dapat menjadi salah satu motivasi dilakukannya income minimization oleh CEO baru. Political Cost Hypothesis berasumsi bahwa politikus atau pemerintah akan lebih memberikan perhatian yang besar pada perusahaan dengan laba yang tinggi, berkaitan dengan pelaksanaan peraturan atau undang-undang yang ada. Biaya politis muncul dikarenakan profitabilitas perusahaan yang tinggi dapat menarik perhatian media dan konsumen. Perhatian media, konsumen dan pemerintah pada khususnya akan memberikan batasan bagi kinerja perusahaan, sehingga perusahaan akan lebih 
Ni Putu Eka Kartika Putri dan I Wayan Ramantha. Pengaruh ...

banyak mendapatkan sorotan berkaitan dengan pelaksanaan undang-undang atau peraturan-peraturan yang berlaku (Halim, 2005).

Penelitian ini menghasilkan simpulan mengenai bagaimana pengaruh pergantian CEO pada profitabilitas yang dimoderasi vaariabel manajemen laba. Hasil dari penelitian ini memberikan gambaran bagaimana keadaan profitabilitas perusahaan setelah terjadinya event pergantian CEO dan mendeteksi keberadaan praktik manajemen laba serta bagaimana interaksi manajemen laba dengan pergantian CEO dan profitabilitas perusahaan. Penelitian ini membuktikan bahwa manajemen laba memoderasi pengaruh pergantian CEO pada profitabilitas. Terdapat peran manajemen laaba berupa income minimization atas rendahnya profitabilitas perusahaan manufaktur yang terdaftar di BEI. Profitabilitas perusahaan dengan nilai rata-rata sebesar 5,06 menunjukkan bahwa profitabilitas perusahaan terbilang cukup rendah.

Penelitian ini diharapkan memberikan kontribusi positif bagi semua pihak yang memerlukan baik investor, perusahaan maupun peneliti lain di masa yang akan datang. Bagi pihak perusahaan, disarankan untuk memilih CEO dengan kualifikasi terbaik karena CEO merupakan kunci keberhasilan suatu perusahaan. Dilihat dari hasil penelitian bahwa pergantian CEO memiliki hubungan searah dengan profitabilitas, disarankan perusahaan menetapkan periode pergantian CEO, dengan adanya pergantian CEO secara rutin diharapkan akan meningkatkan profitabilitas perusahaan dengan inovasi baru yang dibawa oleh CEO baru.

Bagi investor, diharapkan lebih memperhatikan keadaan profitabilitas perusahaan yang dalam penelitian ini diproksikan dengan ROA sesudah event 
pergantian CEO karena ditemukannya indikasi praktik manajemen laba berupa income minimization yang memoderasi profitabilitas perushaan.

Bagi peneliti selanjutnya, diharapkan dapat memberikan dasar yang cukup untuk dikembangan ke penelitian berikutnya dan dapat memberikan inspirasi untuk mengeksplor variabel independen lainnya yang dapat menjelaskan perubahan profitabilitas perusahaan mengingat $93,1 \%$ perubahan profitabilitas dipengaruhi oleh variabel diluar model regresi yang digunakan dalam penelitian ini.

\section{SIMPULAN}

Manajemen laba memoderasi pengaruh pergantian CEO pada profitabilitas. Variabel interaksi pergantian CEO dengan manajemen laba memiliki hubungan yang berlawanan arah dengan profitabilitas. Hubungan yang berlawanan arah adalah semakin banyak partisipasi CEO baru dalam melakukan praktik manajemen laba, maka profitabilitas perusahaan akan semakin turun.

Penelitian ini menggunakan ROA sebagai proksi dari profitabilitas, peneliti selanjutnya dapat menggunakan atau menambahkan rasio profitabilitas lain yang dapat dijadikan proksi dari profitabilitas. Penelitian ini menggunakan ROA sebagai proksi dari profitabilitas, peneliti selanjutnya dapat menggunakan atau menambahkan rasio profitabilitas lain yang dapat dijadikan proksi dari profitabilitas seperti profit margin atau Return on Equity (ROE) (Wiagustini, 2014). Peneliti selanjutnya juga bisa menggunakan variabel kinerja keuangan sebagai pengganti dari profitabilitas untuk cakupan penelitian yang lebih luas. 
Ni Putu Eka Kartika Putri dan I Wayan Ramantha. Pengaruh ...

Penelitian ini menggunakan discretionary accual jones modified untuk mengukur manajemen laba. Peneliti selanjutnya dapat menggunakan model pengukuran manajemen laba lainnya seperti model Healy, model De Angelo, model Jones (Sulistyanto, 2008).

Bagi perusahaan disarankan untuk lebih memerhatikan kebijakan yang diambil oleh CEO baru mengenai praktik manajemen laba. Ditemukannya praktik manajemen laba yang memoderasi perubahan profitabilitas, dapat menurunkan kepercayaan investor dan pemegang saham pada perusahaan.Bagi investor disarankan untuk lebih memperhatikan keadaan profitabilitas perusahaan yang dalam penelitian ini diproksikan dengan ROA sesudah event pergantian CEO karena ditemukannya indikasi praktik manajemen laba berupa income minimization yang memoderasi profitabilitas perushaan.

\section{REFERENSI}

Adiasih, P., \& Kusuma, W. I. (2011). Manajemen Laba Pada Saat Pergantian CEO (Dirut) Di Indonesia. Jurnal Akuntansi Dan Keuangan, 13(2), 67-79. Retrieved from http://puslit2.petra.ac.id/ejournal/index.php/aku/article/view/18458

Affandi, B. I. (2017). Pengaruh Perputaran Modal Kerja, Struktur Modal dan Total Asset Turn Over terhadap Profitabilitas (Studi Empiris pada Perusahaan Manufaktur Sektor Food and Beverage yang terdaftar di BEI tahun 2012-2016), 1-14.

Agnes, U. W. (2001). Analisis Faktor-Faktor Yang Berpengaruh Terhadap Earnings Management Pada Perusahaan Go Public Di Indonesia. Jurnal Akuntansi Dan Keuangan, 3, pp.89-101. Retrieved from http://puslit2.petra.ac.id/ejournal/index.php/aku/article/view/15682

Ajeng Ferdina, N. W., \& Wirama, D. G. (2017). Pengaruh Profitabilitas, Leverage, Likuiditas Dan Ukuran Perusahaan Pada Ketepatwaktuan Laporan Keuangan Ni. ISSN: 2302-8556 E-Jurnal Akuntansi Universitas Udayana 
Vol.19.3. Juni (2017): 2293-2318 PENGARUH, 19, 2293-2318.

Astika, I. B. P. (2010). Teori Akuntansi : Konsep-Konsep Dasar Akuntansi Keuangan.

Boediono, G. S. (2005). Kualitas Laba: Studi Pengaruh Mekanisme Corporate Governance dan Dampak Manajemen Laba dengan Menggunakan Analisis Jalur. Simposium Nasional Akuntansi VIII, VIII(September), 172-194.

Brigham, E. F., \& Houston, J. F. (2006). Dasar-dasar Manajemen Keuangan (Vol. Edisi 10.).

Chandra, D. K. (2013). Pengaruh Pergantian Ceo (Chief Executive Officer) Terhadap Kinerja Perusahaan Dengan Manajemen Laba Sebagai Variabel Intervening (Studi Empiris pada Perusahaan Manufaktur yang Terdaftar di Bursa Efek Indonesia), 1-8.

Dechow, P., Hutton, A., Kim, J. H., \& Sloan, R. G. (2011). Detecting earnings management: A new approach. Journal of Accounting, 50(1), 275-334.

Dewi, N. M. A. K., \& Rasmini, N. K. (2018). Perbedaan Earnings Management pada Pergantian Chief Executive Officer pada Perusahaan Manufaktur yang Terdaftar di BEI, 23, 1442-1469. https://doi.org/10.24843/EJA.2018.v23.i02.p24

Dhinata, I. P. S., \& Wirama, D. G. (2015). Manajamen Laba Pada Event Pergantian Chief Executive Officer Di Perusahaan Yang Terdaftar Di Bursa Efek Indonesia, 2, 326-339.

Erawan, I. G. P., \& Ulupui, I. G. K. A. (2013). Manajemen Laba Sebelum Dan Sesudah Pergantian Chief Executive Officer ( CEO ), 1, 55-72.

Feng Yu, C. (2012). CEO Turnover, Earnings Management, and Big Bath, 1-41.

Halim, A. (2005). Analisis Investasi, (edisi ke-2).

Hannan, M. T., \& Freeman, J. (1977). The Population Ecology of Organizations. American Journal of Sociology, 82(5), 929-964. https://doi.org/10.1086/226424

Hazarika, S., Karpoff, J. M., \& Nahata, R. (2011). Internal corporate governance, CEO turnover, and earnings management.

Healy, P. M., \& Wahlen, J. M. (1999). A Review of the Earnings Management Literature and its Implications for Standard Setting. SSRN Electronic Journal, (November). https://doi.org/10.2139/ssrn.156445 
Kanga, J., \& Shivdasani, A. (1995). Firm performance, corporate governance, and top executive turnover in Japan. Journal of Financial Economics 38 (1995) 29-58, 38, 29-58.

Kaudin, A. (2015). Persepsi Etis Pelaku Akuntansi Terhadap Praktik Manajemen Laba, (August), 0-16.

Muravyev, A., Talavera, O., Bilyk, O., \& Grechaniuk, B. (2009). Firm Performance and Managerial Turnover: Firm Performance and Managerial Turnover : The Case of Ukraine, (4372).

PSAK. (2017). Standar Akuntansi Keuangan. Dewan Standar Akuntansi Keuangan Ikatan Akuntansi Indonesia.

Rachpradit, P., Tang, J. C. S., \& Khang, D. B. (2015). Corporate Governance Emerald Article: CEO turnover and firm performance, evidence from Thailand, (April 2012). https://doi.org/10.1108/14720701211214061

Ratnasari, Y. (2011). Pengaruh Corporate Governance terhadap Luas Pengungkapan Tanggung Jawab Sosial Perusahaan di dalam Sustainability Report.

Sadia, N. P. M. D., \& Sukartha, I. M. (2011). Laba Perusahaan Manufaktur Yang Terdaftar Di Bursa Efek Indonesia. E-Jurnal Universitas Udayana, 2(1), 120 .

Salim, H. (2015). Analisis Pengaruh Manajemen Laba Terhadap Profitabilitas Perusahaan Dengan Good Corporate Governance sebagai Variabel Moderasi:Studi Pada Perusahaan Manufaktur yang Terdaftar di BEI periode 2010-2012. Jurnal Manajemen, 12(1), 68-92.

Setiaji, B., \& Junarsin, E. (2014). Pengaruh Pergantian Chief Executive Officer Terhadap Kinerja Perusahaan Di Indonesia, 15-28.

Sulistiani, D., \& Maha, F. W. O. (2012). Analisis Manajemen Laba dan Kinerja Operasi Terhadap Profitabilitas pada Perusahaan Go Public yang Melakukan Initial Public Offering (IPO).

Sulistyanto, H. S. (2008). Manajemen Laba Teori dan Model Empiris.

Trisnantari, A. N. (2008). Pengaruh Corporate Governance Pada Hubungan Pergantian Chief Executive Officer Dengan Kinerja Perusahaan, (1).

Ung, D. (2009). Earnings management surrounding CEO changes in the Netherlands. 
Wandeca, J. S. (2012). Analisis Pengaruh Pergantian Chief Executive Officer (CEO) Terhadap Praktek Manajemen Laba (Studi Pada Perusahaan BUMN dan Non BUMN di Bursa Efek Indonesia ). Retrieved from http://www.journals.uchicago.edu/doi/10.1086/226424

Wiagustini, N. luh P. (2014). Dasar-Dasar Manajemen Keuangan. Denpasar. Udayana University Press.

Wijaya, B. A., \& Ardiana, P. A. (2014). Manajamen Laba Pada Peristiwa Pergantian, 2, 263-278.

Yasa, G. W., \& Novialy, Y. (2012). Indikasi Manajemen Laba Oleh Chief Executive Officer (Ceo) Baru Pada Perusahaan-Perusahaan Yang Terdaftar Di Pasar Modal Indonesia Gerianta. Jurusan Akuntansi, Fakultas Ekonomi Universitas Udayana ABSTRAK, 1-24. 